\title{
Research on Social Responsibility Information Disclosure of Listed Dairy Companies in China
}

\author{
Dan Wang, Feixian Liu \\ Beijing Wuzi University of Accounting, Beijing, China \\ Email: wangdan9080@sohu.com,605810564@qq.com
}

How to cite this paper: Wang, D. and Liu, F.X. (2018) Research on Social Responsibility Information Disclosure of Listed Dairy Companies in China. Journal of Service Science and Management, 11, 323-332. https://doi.org/10.4236/jssm.2018.113022

Received: April 27, 2018

Accepted: June 19, 2018

Published: June 22, 2018

Copyright ( 92018 by authors and Scientific Research Publishing Inc. This work is licensed under the Creative Commons Attribution-NonCommercial International License (CC BY-NC 4.0). http://creativecommons.org/licenses/by-nc/4.0/ (c) (i) (8) Open Access

\begin{abstract}
Taking the report data of 10 listed dairy companies in China in 2016 as the research sample, it is found that the disclosure subject of New Hope Group is New Hope Liuhe Co., Ltd. and its subsidiaries, and it is considered that its report hardly involves dairy industry activities. Therefore, it was excluded from the valid sample; Feihe Group was listed in New York, USA, and could not obtain the relevant report, so it was excluded as a valid sample. In this paper, the situation of social responsibility information disclosure is analyzed in detail, and the problems existing in the social responsibility information disclosure of the whole industry are picked out by typical individuals. And from three aspects of the information disclosure content, the standard, and the function, the countermeasure and the suggestion are put forward.
\end{abstract}

\section{Keywords}

Dairy Listed Company, Social Responsibility, Information Disclosure

\section{The Analysis of the Current Situation of Social Responsibility Information Disclosure of Listed Dairy Companies in China}

British scholar Ehrlich. Shelton as early as in 1924 put forward the concept of "corporate social responsibility". He thinks that enterprise in the pursuit of economic profit at the same time should not ignore the moral ethics related to social responsibility. In China Enterprise Management Yearbook (1990), there is a definition of the concept: corporate social responsibility, which can be expressed as the responsibility and obligation of enterprises to be concerned and fully performed for the comprehensive and long-term interests of the society in place, as well as the participation of enterprises in the adaptation and development of society. The content of corporate social responsibility is extremely rich: both 
compulsory legal responsibility and conscious moral responsibility. Corporate social responsibility is more important than mount Taishan. Every enterprise should take the social responsibility in the most sincere attitude, safeguard the overall interests of the society, and promote the harmonious development of enterprises and society.

\subsection{The Selection of the Basis for Preparation Is Subjective}

Table 1 shows: In the effective sample, 6 listed companies have issued social responsibility reports, among which only Beingmate's social responsibility report

Table 1. Basis for social responsibility information disclosure of listed dairy companies in 2016 .

Quoted company

Mengniu dairy industry [1]

Yili shares [2]

Bright dairy industry [3]

Ternary stock $[4]$

China Modern Dairy

Holdings Ltd. [5]

(2014)

Beingmate [6]

Yantang dairy industry [7]

Tianrun dairy industry [8]
Basis for the preparation of reports

The Stock Exchange of Hong Kong (guidelines for Environmental, Social and Control reports)

G4 Global reporting Initiative Guide for Sustainable Development reporting

GB/T36001-2015 Guide to the preparation of Social responsibility reports

Guide to the compilation of the Food Industry Social responsibility report of the Chinese Academy of Social Sciences

International Organization for Standardization (ISO 26000: a Guide to Social responsibility 2010)

China Dairy Industry Standard RHB901-2016 Dairy Enterprise Social responsibility Guide

Global reporting Initiative (GRI) "guidelines for Sustainable Development reporting"/G4

Ten principles of the United Nations Nationals Global Compact

International Organization for Standardization (ISO 26000: a Guide to Social responsibility 2010)

GB/T36001-2015 Guide to the preparation of Social responsibility reports

Guide to the compilation of the Food Industry Social responsibility report of the Chinese Academy of Social

Sciences 3.0

Notice issued by the Shanghai Stock Exchange on strengthening the Social responsibility of listed companies and issuing the guidelines on Environmental Information Disclosure of listed companies on the Shanghai Stock

Exchange

"notice on the further improvement of Information Disclosure on Poverty reduction by listed companies" issued by the Shanghai Stock Exchange

Guide to the compilation of the Food Industry Social responsibility report of the Chinese Academy of Social Sciences

Global reporting Initiative (GRI) "guidelines for Sustainable Development reporting”/G4

Global reporting Initiative (GRI) "guidelines for Sustainable Development reporting"/G4

State Council SASAC "guidance on state-owned enterprises to better fulfill their social responsibilities"

Beijing SASAC "guiding opinion on the implementation of Social responsibility of Municipal State-owned Enterprises"

Shanghai Stock Exchange "guidelines for the compilation of reports on Corporate performance of Social responsibility"

Chinese Academy of Social Sciences < Guide to the compilation of Chinese Corporate Social responsibility report [CASS-CSR 3.0]

The Stock Exchange of Hong Kong (guidelines for Environmental, Social and Governance reports)

GRI Sustainable Development reporting guidelines for the Global reporting Initiative

Disclosure targets required by supplementary guidelines for the food processing industry

not have 
does not mention the basis of compilation, while the others all list the basis of compilation, but the basis of compilation is different, and the choice is subjective. In addition, only the social responsibility report of Mengniu Dairy Industry 2016 has certain professional standard and high disclosure reliability.

\subsection{Significant Differences in Format and Length of Disclosure}

Continuity of the Social Responsibility Report: The first corporate citizenship report began in 2006, and seven separate reports on social responsibility were continuously released; Mengniu Dairy released its first report on Social Responsibility Report-Sharing Results (1999-2007) in 2008, followed by a series of four independent social responsibility reports; The Bright dairy industry published seven independent social responsibility reports for seven consecutive years in 2010-2016; The Ternary stock issued its first social responsibility report in 2014, and the report on social responsibility has been issued for three consecutive years; Tianrun Dairy Industry hasn't started yet. A social responsibility report was distributed; modern animal husbandry released its first sustainable development report in 2014, one in all; and Yantang dairy industry did not publish a social responsibility report. In general, the awareness of social responsibility information disclosure of listed dairy companies is enhanced, and the awareness of independent disclosure is gradually improved.

Social responsibility information disclosure generally takes the form of an independent social responsibility report (sustainable development report), board report, and annual report. Independent social responsibility reports are more specific and professional than others. The social responsibility reports published by eight listed dairy companies in 2016 are 70 pages [1] of Mengniu, 45 pages [2] of Yili, 44 pages [3] of Guangming, 57 pages [4] of San Yuan and 50 pages [6] of Beimei, 63 pages [5] of Modern Animal Husbandry in 2014. Yantang Dairy and Tianrun Dairy only have 2 pages [7] [8]. As can be seen, the number of social responsibility reports is maintained at more than 40 pages, the content is relatively rich.

\subsection{The Disclosure Is Not Comprehensive Enough}

\subsubsection{Content Definition of Corporate Social Responsibility Information Disclosure}

After summarizing the previous research results, based on the relevant theory and the latest relevant regulations, this paper summarizes the nine main categories of social responsibility information disclosure content of dairy enterprises, in light of the actual situation of dairy enterprises in China. There are: social responsibility management, product development and innovation, customer service, product responsibility chain, employee care, shareholder responsibility, social welfare, environmental protection, government [9].

1.3.2. Index Score of Corporate Social Responsibility Information Disclosure In order to reflect the actual situation of the research sample more intuitively 
and vividly, this paper adopts the index research method, which is widely used by experts and scholars, assigns the above contents of the social responsibility information disclosure, and then adds up the statistics [10]. To evaluate the level of social responsibility information disclosure of listed dairy companies through the total score. The assignment is divided into three categories: undisclosed "0", qualitative disclosure " 1 " and quantitative disclosure " 2 ". By using the cumulative sum method, each item has the highest score of 3 points and the lowest score of 0 points [10]. Therefore, eight listed dairy companies in 2016 social responsibility report information disclosure score statistics are as follows:

The score of Table 2 showed that the level of social responsibility information disclosure in the eight valid samples was polarized. Four listed companies scored more than 45 points, while the other four had a score of 25 to 30 . Overall, the practice of social responsibility is better than that of social responsibility management.

\subsubsection{Analysis and Summary of Social Responsibility Information Disclosure of Listed Dairy Companies \\ 1) Social responsibility management}

In the social responsibility report of five listed dairy companies in 2016: all of them have disclosed the contents of the concept of social responsibility, and Tianrun Dairy and Yantang Dairy also have related contents in their 2016 annual reports. Only one has not been disclosed; and social responsibility planning, social responsibility leadership mechanisms, social responsibility issues identification and disclosure of the number of companies, only Mengniu dairy industry disclosure is complete.

\section{2) Product development and innovation}

Of the eight valid samples, five listed dairy companies have disclosed quality and safety issues in their 2016 social responsibility reports. Research and development investment. Yili group disclosed that the total investment in $\mathrm{R} \& \mathrm{D}$ in the whole year was 17,196.22 million yuan [2], and Ternary stock investment in scientific research amounted to 309,356 yuan [4]. Tianrun dairy disclosed in its annual report that its $\mathrm{R} \& \mathrm{D}$ investment was $1,679,040.58$ yuan [8] and yantang dairy's total R \& D investment was 31,585,612.07 yuan [7]. The remaining valid samples only qualitatively disclose the relevant content of product development.

\section{3) Customer service}

In response to customer complaints, the social responsibility reports of 2016 of the 5 listed dairy companies all have qualitative disclosure. In 2016, Yili Group invested more than 500,000 yuan [2] in food quality and safety training complaints to management, internal auditors, new employees, and supplier auditors. Tianrun Dairy, Yantang Dairy, Modern Animal Husbandry Annual report is not disclosed. About customer satisfaction Survey Yili Group disclosed the best, and established a customer satisfaction evaluation system. The average customer satisfaction rate in 2016 was over $99 \%$, which was higher than the level

of the same industry; Tianrun Dairy, Yantang Dairy, Modern Animal Husbandry 
Table 2. Social responsibility disclosure scores of listed dairy companies in 2016.

\begin{tabular}{|c|c|c|c|c|c|c|c|c|c|}
\hline Hot topic & Sub-topic & Mengniu & $\begin{array}{c}\text { Yili } \\
\text { shares }\end{array}$ & $\begin{array}{c}\text { Bright } \\
\text { dair }\end{array}$ & Ternary & Beingmate & $\begin{array}{c}\text { Tianrun } \\
\text { dairy }\end{array}$ & $\begin{array}{c}\text { Yantang } \\
\text { dairy }\end{array}$ & $\begin{array}{c}\text { Modern } \\
\text { Dairy. }\end{array}$ \\
\hline \multirow{6}{*}{$\begin{array}{c}\text { Social responsibility } \\
\text { management }\end{array}$} & Corporate social responsibility concept & 1 & 1 & 1 & 1 & 1 & 1 & 1 & 1 \\
\hline & Social responsibility planning & 1 & 1 & 0 & 1 & 0 & 0 & 0 & 0 \\
\hline & Social responsibility leadership agency & 1 & 1 & 0 & 1 & 0 & 0 & 0 & 0 \\
\hline & Social responsibility topic identification & 1 & 1 & 0 & 0 & 0 & 0 & 0 & 0 \\
\hline & Stakeholder communication & 1 & 1 & 1 & 1 & 0 & 0 & 0 & 1 \\
\hline & Total & 5 & 5 & 2 & 4 & 1 & 1 & 1 & 2 \\
\hline \multirow{3}{*}{$\begin{array}{c}\text { Product } \\
\text { development and } \\
\text { innovation }\end{array}$} & Quality safety & 3 & 3 & 1 & 3 & 1 & 1 & 1 & 1 \\
\hline & Research and development investment & 1 & 3 & 1 & 3 & 1 & 3 & 3 & 1 \\
\hline & Total & 4 & 6 & 2 & 6 & 2 & 4 & 4 & 2 \\
\hline \multirow{3}{*}{ customer service } & Actively respond to customer complaints & 1 & 3 & 3 & 1 & 1 & 0 & 0 & 0 \\
\hline & Customer satisfaction survey & 0 & 3 & 1 & 1 & 0 & 0 & 0 & 0 \\
\hline & Total & 1 & 6 & 4 & 2 & 1 & 0 & 0 & 0 \\
\hline \multirow{3}{*}{$\begin{array}{l}\text { Product liability } \\
\text { chain }\end{array}$} & Supplier Vendor Management & 3 & 3 & 3 & 3 & 0 & 1 & 1 & 3 \\
\hline & Distributor cooperation & 3 & 3 & 1 & 0 & 0 & 1 & 0 & 0 \\
\hline & Total & 6 & 6 & 4 & 3 & 0 & 2 & 1 & 3 \\
\hline \multirow{6}{*}{ Employee care } & Staff training & 3 & 3 & 3 & 3 & 0 & 1 & 1 & 1 \\
\hline & Employee career development channel & 1 & 1 & 1 & 1 & 0 & 0 & 0 & 0 \\
\hline & Occupational health and safety & 3 & 3 & 1 & 3 & 0 & 1 & 0 & 0 \\
\hline & Female management & 3 & 3 & 0 & 1 & 0 & 0 & 0 & 0 \\
\hline & Wages, salaries and benefits & 1 & 1 & 1 & 1 & 3 & 3 & 3 & 3 \\
\hline & Total & 11 & 11 & 6 & 9 & 3 & 4 & 4 & 4 \\
\hline \multirow{3}{*}{ Shareholder liability } & corporate governance & 3 & 3 & 3 & 3 & 3 & 3 & 3 & 3 \\
\hline & economic performance & 3 & 3 & 3 & 3 & 3 & 3 & 3 & 3 \\
\hline & Total & 6 & 6 & 6 & 6 & 6 & 6 & 6 & 6 \\
\hline \multirow{5}{*}{$\begin{array}{l}\text { Social welfare Social } \\
\text { welfare }\end{array}$} & Enterprise public welfare concept & 1 & 1 & 1 & 0 & 1 & 1 & 1 & 1 \\
\hline & Brand public welfare project & 3 & 3 & 3 & 3 & 3 & 1 & 1 & 1 \\
\hline & Total donations & 3 & 3 & 3 & 3 & 3 & 3 & 0 & 3 \\
\hline & Provide employment & 3 & 3 & 0 & 0 & 0 & 1 & 0 & 0 \\
\hline & Total & 10 & 10 & 7 & 6 & 7 & 4 & 2 & 5 \\
\hline \multirow{4}{*}{$\begin{array}{l}\text { environmental } \\
\text { protection }\end{array}$} & Pollution Control, Energy Saving & 3 & 3 & 3 & 3 & 0 & 3 & 3 & 1 \\
\hline & Green pasture & 3 & 3 & 3 & 3 & 0 & 3 & 0 & 1 \\
\hline & Environmental protection technology innovation & 3 & 0 & 0 & 1 & 0 & 1 & 1 & 0 \\
\hline & Total investment in environmental protection & 3 & 3 & 3 & 3 & 0 & 0 & 0 & 0 \\
\hline \multirow{4}{*}{ government } & Total & 12 & 9 & 9 & 10 & 0 & 7 & 4 & 2 \\
\hline & observe law and discipline & 1 & 3 & 1 & 3 & 1 & 1 & 1 & 1 \\
\hline & Active taxation & 3 & 3 & 3 & 3 & 3 & 3 & 3 & 3 \\
\hline & Total & 4 & 6 & 4 & 6 & 4 & 4 & 4 & 4 \\
\hline & In short & 49 & 50 & 46 & 50 & 26 & 34 & 28 & 30 \\
\hline
\end{tabular}


Annual report is not disclosed.

\section{4) Product liability chain aspect}

Supplier management and dealer cooperation, only Mengniu Dairy and Yili Group to this disclosure. In 2016, Mengniu had 367 suppliers of raw and auxiliary materials and 96 suppliers of raw and auxiliary materials strategy [1], which realized the integration of selection, management and responsibility. Yili all industry chain hand in hand to advance hand in hand, in 2016 with cooperative supplier $100 \%$ sign "supplier business integrity and anti-fraud management notice" $100 \%$ sign "sunshine agreement" [2], effectively solve the upstream and downstream small, agricultural and rural enterprises financing needs.

\section{5) Employee care}

Employee training information. Four of the five social responsibility reports disclosed information that beingmate did not disclose. Employee career development channel. Mengniu, Yili and Sanyuan all revealed the two-channel career development path, stratified and classified the training of employees, and Guangming dairy initiated the "lead over plan". Occupational health and safety. Three listed dairy companies have reported 100\% medical coverage. The 2016 annual reports of Tianrun dairy, Yantang dairy and modern ranching all contain qualitative disclosure of occupational safety information. Women management. Mengniu dairy, Yili group and Sanyuan food attach importance to the protection of female employees, which is more prominent.

\section{6) Shareholder liability}

Corporate governance. Mengniu, Yili Group, Bright Dairy and Ternary stock are disclosed to achieve an effective corporate governance structure. Economic performance. Effective samples all disclosed this, for example, the operating income of Mengniu amounted to 537.800 billion yuan, and the gross profit was 176.4 billion yuan [1]; The light dairy industry realized the operating income of 202. 07 billion yuan, net profit of RMB 6.75 billion yuan [3].

\section{7) Social welfare}

Corporate public welfare concept. Mengniu and Bright dairy have a clear definition. For example, Bright dairy adheres to the concept of "boundless love and boundless light" and strives to give back to the society with practical actions. Total donations. Yili group has invested a total of 800 million yuan in public welfare undertakings, and donated 8.074 million yuan in 2016. Provide jobs [2]. Mengniu has set up 58 factories in 33 production bases nationwide [1], giving priority to hiring local employees and providing employment opportunities. Yili group actively promotes local employment and employment of vulnerable groups.

\section{8) Environmental protection}

Mengniu, Yili and Sanyuan have done well in pollution control and energy conservation. Green pastures. Mengniu, Yili have disclosed. For example, all the self-owned pastures of Yili group have been equipped with facilities such as rain and pollution diversion, dry and wet separation and other facilities, realizing the zero emission mode of "planting and breeding combined with fecal pollution 
resource recycling". Total investment in environmental protection. In 2016, mengniu invested 1,277,000 yuan in environmental protection technology transformation [1]. Yili group is committed to continuous investment in green production, green pastures, green buildings and other projects with a total investment of 160 million yuan [2]. The total investment of sanyuan food in environmental protection reached 1.96 million yuan in 2016 [4]. Beingmate did not disclose this.

\section{9) Government side}

Obey the law. All of these companies have performed well. Among them, the most detailed disclosure is the ternary shares, including strengthening party conduct, serving the country's strategy, and promoting supply-side reforms. All the 8 valid samples are active tax payers. Mengniu paid 2.92 billion yuan in 2016 [1]; Yili 2016 paid 38.18239 billion yuan [2]; and Ternary stock paid 309 million yuan in 2016 [4].

\section{Problems in Social Responsibility Information Disclosure of Listed Dairy Companies in China}

\subsection{Content}

There are still some problems in the disclosure of social responsibility information of listed companies in dairy industry in China, which are mainly characterized by low reliability, low correlation and low comparability. Firstly, lack professional third-party authentication and low reliability. Only Mengniu Dairy issued a Social responsibility report validation statement at the end of the report, which was examined by Hande Technical Supervision Services (Asia Pacific) Ltd. Secondly, although the relevant departments of the state have issued numerous regulations around fulfilling corporate social responsibility and disclosure of information, there are only guidelines and norms, and there is no mandatory requirement for disclosure. It is normal to report good things to the public companies, and only to disclose the outstanding achievements of the companies. And the problems that arise often pass by or even never mention. By The incomplete disclosure of information will often affect readers' perception and evaluation of the company's status and even affect their stakeholders' economic decisions. Thirdly, the social responsibility reports disclosed by the listed dairy companies in China vary from the title format, the order of the contents, the level of detail of the contents, the design style of the reports, and so on. Due to the lack of mandatory regulatory requirements, different listed companies may adopt different disclosure methods for similar economic businesses, which may cause deviation of information disclosure among enterprises, and also affect the comparability of information. Finally, the research and decision-making for information users will cause a certain degree of distress.

\subsection{Standard}

Among the 8 valid samples, Mengniu Dairy Industry, Yili Group, Bright dairy 
and Ternary stock, as the giants of dairy industry, have a high level of social responsibility information disclosure. However, the level of information disclosure of other smaller and less powerful enterprises is slightly inadequate. Corporate social responsibility (CSR) is the product of new social responsibility. More and more companies realize the importance of sustainable development and social harmony. Everyone has poured into the army of voluntary disclosure of social responsibility information, but for companies that are just beginning and limited in scale, the pursuit of a high level of disclosure of social responsibility information with benchmarking enterprises is obviously not very realistic, after all, for any enterprises, ensuring certain economic benefits is the most basic requirement. Some scholars have shown that the level of corporate social responsibility information disclosure is positively related to the scale of enterprises, and the enterprises with higher profits invest more in social responsibility investment. Therefore, we cannot rigidly use the same eyes, standards to evaluate the level of social responsibility information disclosure of all listed companies.

\subsection{Impact}

The purpose of corporate social responsibility is, on the one hand, to really do some good for society, so that the public can better understand enterprises and products, and on the other hand, through the disclosure of social responsibility information, Stakeholders' views collected in place to help enterprises make better progress. By 2016, China has released about thousands of copies responsibility reports. But who is reading these reports? Did it play its rightful role? Also for the dairy industry, how many people are looking at the social responsibility information disclosed? In the process of writing this paper, I felt the hard work of collecting reports. There are several companies in their offices Net has clear social responsibility column, can download directly, but the social responsibility report of most companies is not easy to find. Well, in this way, apart from experts, researchers and stakeholders, the rest of the population will hardly and will not easily see the disclosure of social responsibility information, and people's understanding of social responsibility reports is even less. Data show that $90 \%$ have not read the report [3]. The role of CSR report cannot be given full play.

\section{Suggestions on Improving Social Responsibility Information Disclosure of Listed Dairy Companies in China}

On the basis of summing up the achievements of many experts and scholars, this paper puts forward the following suggestions for improvement from the three angles of "content, standard and function" in view of the main problems of social responsibility information disclosure of listed companies in dairy industry.

\subsection{Define the Quality Requirements of Social Responsibility Information Content in Dairy Industry}

At present, there are only guidelines on the social responsibility of dairy industry 
in China. On June 3, 2016, the China Dairy Industry Association issued the first "Guide to Social Responsibility of Dairy Enterprises". The Guide defines the core content of corporate social responsibility and provides reference and guidance for the dairy industry to improve its capacity for sustainable development. But there is no constraint of compulsion, neglecting the inherent, that is, the quality requirement of social responsibility information: Enterprises should disclose according to the actual events, truthfully reflect the relevant contents of the disclosure requirements, and may not arbitrarily select the best and inferior, to ensure that the disclosed social responsibility information has reliability, relevance and comparability. Because the accounting information disclosure content design itself is not standardized, the following situation occurred: 1) The information distortion phenomenon is serious, and the reliability of the disclosed accounting information content cannot be guaranteed. 2) The disclosure of accounting information is not relevant enough, and the content deviates from the needs of information users.

\subsection{Establish a Scientific Social Responsibility System for Dairy Industry}

In order to better meet the requirements of information users and protect the rights and interests of consumers, the corresponding standards should be formulated according to the industry category, the size of the company and the characteristics of the operating products. For example, for large enterprises with registered capital of 10 million or more, corporate social responsibility reporting standards should be adopted for listed companies, while for those with insufficient registered capital, the social responsibility reporting standards for small and medium-sized enterprises will be adopted. Under each standard, further refinement of information disclosure guidelines, such as the specific content of disclosure (good or bad) should be reported one by one: the format of disclosure, the order of disclosure, third party audit, etc. In this way, a scientific enterprise social responsibility system is established step by step from the whole standard, the industry internal standard and the implementation rules so as to urge the enterprise to truly disclose the social responsibility information which can reflect the characteristics of the dairy industry.

\subsection{Strengthen Social Responsibility Communication of Listed Dairy Companies [11]}

The social responsibility of publishing enterprises is an important way for enterprises to strengthen and communicate with society. With the change of the social environment and the improvement of the social citizen consciousness, the stakeholders constantly strengthen the interest appeal and communication desire of the enterprise. Among the valid samples, only Mengniu, Yili, Ternary have readers' feedback on the end of the page, which shows that few enterprises pay attention to the important link of corporate social responsibility communication. We are in the era of information-based high-speed development, enter- 
prises should fully apply the Internet, through various media communication platforms, truly transmit the social responsibility report out, bring the views of the public and stakeholders back to the enterprise, and continue to improve and continue to develop, so that the role of the social responsibility information disclosure is really played out.

\section{Funding}

This article is funded by Beijing philosophy and social science planning project (16GLB021).

\section{References}

[1] Nei Monggol: Mengniu Dairy Co., Ltd. (2017) 2016 China Mengniu Dairy Co Sustainable Development Report. http://www.mengniu.com.cn/duty/mngy/

[2] Nei Monggol: Yili Industrial Group Co., Ltd. (2017) Social Responsibility Report of Inner Mongolia Yili Industry Group Co., Ltd. for 2016. http://www.yili.com/cms/rest/reception/files/list?categoryId=41

[3] Bright Dairy Co., Ltd. (2017) Social Responsibility Report 2016. Bright Dairy Co., Ltd., Shanghai. http://www.brightdairy.com/about/

[4] Beijing Sanyuan Group Co., Ltd. (2017) Report on Social Responsibility of Sanyuan Food 2016. Beijing Sanyuan Group Co., Ltd., Beijing.

http://www.sanyuan.com.cn/aboutus/value.html

[5] Modern Animal Husbandry (Group) Co., Ltd. (2017) 2014 Sustainable Development Report and Annual Report 2016. Modern animal husbandry (Group) Co., Ltd., Anhui. http://www.xiandaimuye.com/

[6] Beimei Baby Food Co., Ltd. (2017) Green Paper on Corporate Social Responsibility. Beimei Baby Food Co., Ltd., Zhejiang. http://www.beingmate.com/

[7] Yantang Dairy Co., Ltd. (2017) Guangdong Yantang Dairy Co., Ltd. 2016 Annual Report. Yantang Dairy Co., Ltd., Guangdong.

http://www.cninfo.com.cn/cninfo-new/disclosure/szse_sme/bulletin_detail/true/120 3111290 announceTime $=2017-02-28$

[8] Tianrun Dairy Co., Ltd. (2017) Xinjiang Tianrun Dairy Co., Ltd. 2016 Annual Report. Tianrun Dairy Co., Ltd., Xinjiang.

http://www.cninfo.com.cn/cninfo-new/disclosure/sse/bulletin_detail/true/12032267 24? announceTime $=2017-03-30$

[9] Dong, S.-L. and Geng, J.-C. (2016) Research on Social Responsibility Information Disclosure of Food Enterprises-Taking SF Enterprises as an Example. The Northern Economy and Trade, 11, 106-108.

http://kns.cnki.net/KCMS/detail/detail.aspx?dbcode=CJFQ\&dbname=CJFDLAST20 16\&filename=GFJM201611045\&v=MjI4ODNMdXhZUzdEaDFUM3FUcldNMUZy Q1VSTEtmWStSb0Z5emhVYjdCSW12Qlk3RzRIOWZOcm85QllZUjhlWDE=

[10] Dong, S.-L. and Geng, J.-C. (2016) Research on Social Responsibility Information Disclosure of Food Enterprises-Taking SF Enterprises as an Example. Northern Economy and Trade, No. 11, 106-108.

http://kns.cnki.net/KCMS/detail/detail.aspx?dbcode=CJFQ\&dbname=CJFDLAST20 16\&filename=GFJM201611045\&v=MjI4ODNMdXhZUzdEaDFUM3FUcldNMUZy Q1VSTEtmWStSb0Z5emhVYjdCSWl2Qlk3RzRIOWZOcm85QllZUjhlWDE=

[11] Li, S.T. (2015) Who Is the CSR Report for. China Youth Daily, 2015-07-14. http://finance.sina.com.cn/china/20150714/061422677682.shtml 